\title{
Pengembangan Model Pembelajaran Pendidikan Kewarganegaraan (PKn) dengan Teknik Debate Make A Match (DMM)
}

\author{
Ida Rachmawati*, Rita Retnowati**, Karantiano** \\ * Mahasiswa Program Studi Administrasi Pendidikan, Program Pascasarjana \\ ** Staf Dosen Program Studi Administrasi Pendidikan, Program Pascasarjana \\ Universitas Pakuan \\ Bogor, Indonesia
}

Diterima: 12 September 2015. Disetujui: 12 Oktober 2015. Dipublikasikan: Januari 2016

\begin{abstract}
Abstrak
Penelitian ini bertujuan untuk mengembangkan model pembelajaran pendidikan kewarganegaraan dengan teknik debate make a match (DMM). Metode penelitian yang digunakan adalah penelitian dan pengembangan (Research and Development). Pada penelitian ini analisis data yang digunakan adalah kualitatif dan kuantitatif. Untuk mengukur uji validitas hasil belajar siswa dengan menggunakan Point Biserial dan uji reliabiltas menggunakan Kuder Richardson-20. Sedangkan hasil belajar afektif dan psikomotor metode kalibrasinya menggunakan expert judgment. Sedangkan hasil belajar afektif dan psikomotor metode kalibrasinya menggunakan expert judgment. Penelitian uji coba terbatas dilaksanakan di SMPN 2 Cicurug Sukabumi dengan jumlah siswa 42 orang, sedangkan uji coba lebih luas di SMP PGRI Cicurug dengan jumlah siswa 29 orang dan di SMPIT AL-HUSNA Parungkuda Sukabumi dengan jumlah siswa 32 orang. Berdasarkan temuan penelitian, analisis data dan refleksi pada setiap uji coba, bahwa penelitian dan pengembangan menghasilkan model terekomendasi, yaitu pengembangan model pembelajaran debate card match (DCM). Desain model pembelajaran DCM terdiri dari input, proses, dan output. Input terdiri dari kurikulum yang diterapkan di sekolah, siswa serta guru mata pelajaran PKn. Proses terdiri dari langkah-langkah model pembelajaran DCM. Output dari pengembangan model pembelajaran DCM adalah : Pengembangan model pembelajaran DCM pada mata pelajaran Pendidikan Kewarganegaraan (PKn), mampu dan terbukti dapat meningkatkan hasil belajar ranah kognitif, afektif dan psikomotor pada uji coba terbatas dan uji coba lebih luas. DCM dapat meningkatkan motivasi dan antusisme siswa dalam proses pembelajaran.
\end{abstract}

(C) 2016 Program Pascasarjana Universitas Pakuan

KATA KUNCl: debate make a match, hasil belajar, Pendidikan Kewarganegaraan

\section{PENDAHULUAN}

Pendidikan merupakan bagian integral dalam pembangunan. Proses pendidikan tidak dapat dipisahkan dari proses pembangunan itu sendiri. Pembangunan diarahkan dan bertujuan untuk mengembangkan sumber daya yang berkualitas. Manusia yang berkualitas dapat dilihat dari segi pendidikan. Hal ini terkandung dalam tujuan pendidikan nasional, bahwa pendidikan nasional bertujuan untuk mencerdaskan kehidupan bangsa seutuhnya, selain beriman bertakwa pada Tuhan Yang Maha Esa serta sehat 
jasmani dan rohani, juga memiliki kemampuan dan keterampilan.

Dalam undang-undang nomor 20 tahun 2003 tentang pendidikan nasional bab I pasal 1 menyebutkan bahwa Pendidikan adalah usaha sadar dan terencana untuk mewujudkan suasana belajar dan proses pembelajaran agar peserta didik secara aktif mengembangkan potensi dirinya untuk memilki kekuatan spiritual keagamaan, pengendalian diri, kepribadian, kecerdasan, akhlak mulia, serta keterampilan yang diperlukan dalam masyarakat, bangsa dan negara.

Undang-undang nomor 14 tahun 2005 tentang guru dan dosen menyatakan bahwa guru adalah pendidik professional dengan tugas utama mendidik, mengajar, membimbing, mengarahkan, melatih, menilai, dan mengevaluasi peserta didik pada pendidikan anak usia dini jalur pendidikan formal, pendidikan dasar, dan menengah.

Sekarang ini guru dituntut lebih kreatif dan inovatif menciptakan model-model pembelajaran yang dapat membuat peserta didik "belajar". Sehingga siswa dapat mengalami langsung proses belajar. Siswa tidak hanya menerima transfer ilmu pengetahuan dari guru tetapi mampu menemukan sendiri konsep materi pembelajaran, dengan demikian peserta didik akan lebih aktif dan kreatif.

Permasalahan proses pembelajaran siswa muncul bersamaan dengan berkembang dan meningkatnya kemampuan siswa serta situasi dan kondisi lingkungan yang ada. Kenyataan di lapangan banyak dijumpai gaya mengajar guru belum maksimal, sehingga proses pembelajaran tidak efektif. Proses pembelajaran yang menggunakan cara pendekatan konvensional sudah dianggap tidak efektif serta menimbulkan kejenuhan di dalam kelas, oleh karenanya guru dituntut untuk selalu terus berupaya memperbaiki pengelolaan pembelajaran.

Kenyataan yang masih banyak ditemui, dalam proses belajar mengajar, prestasi belajar siswa masih banyak yang rendah. Hal ini bisa dibuktikan dengan nilai yang siswa peroleh pada saat siswa telah menyelesaikan tes. Hasil tes siswa masih banyak yang di bawah standar. Hasil tes ini setidaknya mencerminkan seberapa jauh daya serap dan pemahaman siswa terhadap materi pelajaran yang diterimanya.

Berdasarkan hasil pengamatan dan pengalaman selama ini, siswa kurang aktif, dan cenderung tidak tertarik dalam kegiatan pembelajaran mata pelajaran Pendidikan Kewarganegaraan (PKn), karena selama ini mata pelajaran Pendidikan Kewarganegaraan (PKn) dianggap sebagai pelajaran yang hanya mementingkan hafalan semata, kurang menekankan aspek penalaran sehingga menyebabkan rendahnya minat belajar PKn siswa di sekolah. Keaktifan siswa rendah justru disebabkan oleh pembelajaran yang berpusat pada guru. Guru hanya menggunakan model pembelajaran yang bersifat konvensional dan banyak didominasi guru, sehingga mengakibatkan keaktifan siswa rendah.

Berdasarkan informasi dari guru yang mengajar mata pelajaran Pendidikan Kewarganegaraan (PKn) di beberapa SMP Negeri di Cicurug, rata-rata nilai ulangan harian PKn selama tiga tahun terakhir diperoleh data bahwa masih banyak siswa yang nilainya dibawah KKM. Hal ini disebabkan pembelajaran PKn disekolah masih mengacu pada model pengajaran yang masih konvensional. Proses pembelajaran masih berpusat pada guru, sehingga 
pembelajaran menjadi terasa kering, tidak menyenangkan, dan membosankan bagi siswa. Dalam hal ini guru sebagai fasilitator pada proses pembelajaran perlu memberikan respon positif secara konkrit dan objektif yang berupaya membangkitkan partisipasi aktif siswa dalam pembelajaran PKn.

Data empiris yang ada di lapangan pada beberapa SMP Negeri yang ada di Cicurug, pada tiga tahun terakhir, selain nilai ulangan harian yang masih di bawah KKM, juga terlihat dari respon siswa saat proses pembelajaran, dalam satu kali tatap muka (2X40 menit) hanya $40 \%$ siswa yang berani memberikan gagasannya atau jawaban dari pertanyaan yang diberikan guru. Bahkan keberanian siswa untuk bertanya tentang materi yang sedang dipelajari hanya sekitar $30 \%$ saja.

Informasi yang hampir sama juga diperoleh dari guru mata pelajaran Pendidikan Kewarganegaraan (PKn) yang mengajar di beberapa SMP swasta yang ada di Cicurug, bahwa proses pembelajaran mata pelajaran PKn kurang mendapat respon dari para siswa sehingga antusiasme siswa terhadap mata pelajaran PKn sangat rendah dan mempengaruhi terhadap hasil belajar siswa. Siswa merasa terpaksa mengikuti proses pembelajaran, dan siswa kesulitan memahami materi yang disampaikan guru.

Untuk mengatasi permasalahan di atas, salah satu model pembelajaran yang tepat adalah model debat, model ini merupakan salah satu model pembelajaran kooperatif yang melibatkan siswa secara maksimal, kegiatan belajar lebih terarah dan sistematis serta dapat mengembangkan sikap percaya diri, pembelajaran menjadi menarik, menyenangkan dan lebih mudah, terjadi interaksi dalam belajar karena lebih banyak belajar dengan teman sebaya, menuntut tanggung jawab individu maupun kelompok juga berlatih untuk berkompetisi secara positif.

Model pembelajaran debat sangat tepat jika dikombinasikan dengan model permainan yang menyenangkan bagi siswa sambil belajar, yaitu dengan model pembelajaran make a match.

Model pembelajaran make a match merupakan model pembelajaran yang dikembangkan oleh Lorna Curran. Ciri utama model make a match adalah siswa mencari pasangan kartu yang merupakan jawaban atau pertanyaan materi tertentu dalam pembelajaran (Shoimin, 2014). Salah satu keunggulan model ini adalah siswa mencari pasangan sambil belajar mengenai suatu konsep atau topik dalam suasana yang menyenangkan. Selain kelebihan adapula kelemahan model ini, yaitu diperlukan bimbingan dari guru untuk melakukan pembelajaran, suasana kelas menjadi gaduh sehingga mengganggu kelas lain, dan guru perlu persiapan bahan dan alat yang memadai, serta durasi waktu yang tidak lama sehingga model make a match ini harus dilakukan berkali-kali yang akan membuat bosan siswa.

Model pembelajaran active debate/debat aktif dikembangkan oleh Melvin L. Silbermen yang merupakan Guru Besar kajian Psikologi Pendidikan di Temple University dan merupakan salah satu metode atau pendekatan dalam pembelajaran kooperatif. Model ini digunakan untuk menstimulasi diskusi kelas melalui suatu perdebatan antar kelompok diskusi yang disatukan dalam sebuah diskusi kelas. Selain kelebihan adapula kelemahan model ini, yaitu tidak bisa digunakan untuk semua mata pelajaran, proses pembelajaran kurang menarik karena hanya adu pendapat dan tidak menggunakan media pembelajaran, 
membutuhkan waktu yang cukup lama karena siswa harus memahami materi terlebih dahulu sebelum melakukan debat, serta siswa menjadi takut dan tertekan karena harus bisa berkomunikasi secara langsung untuk mengungkapkan pendapatnya (Bambang, 2006).

Berdasarkan permasalahan di atas, dan dengan banyaknya kelemahan-kelemahan yang ada pada setiap model, maka perlu adanya pengembangan model pembelajaran yang lebih efektif, inovatif, dan kreatif untuk mencari jalan keluar agar proses pembelajaran terhadap mata pelajaran Pendidikan Kewarganegaraan (PKn) tidak semakin membosankan dan untuk meningkatkan hasil belajar serta motivasi dan partisipasi siswa baik bertanya, menjawab, serta memberikan ide atau argumen pada pelajaran Pendidikan Kewarganegaraan (PKn), yaitu dengan cara pengembangan serta penerapan model pembelajaran debate make a match (DMM). Pengembangan model pembelajaran ini merupakan kolaborasi atau menggambungkan antara model make a match dengan active debate.

\section{METODE}

Metode penelitian yang digunakan adalah penelitian dan pengembangan (Research and Development). Pada penelitian ini analisis data yang digunakan adalah kualitatif dan kuantitatif. Untuk mengukur uji validitas hasil belajar siswa dengan menggunakan Point Biserial dan uji reliabiltas menggunakan Kuder Richardson20. Sedangkan hasil belajar afektif dan psikomotor metode kalibrasinya menggunakan expert judgment. Sedangkan hasil belajar afektif dan psikomotor metode kalibrasinya menggunakan expert judgment.
Penelitian uji coba terbatas dilaksanakan di SMPN 2 Cicurug Sukabumi dengan jumlah siswa 42 orang, sedangkan uji coba lebih luas di SMP PGRI Cicurug dengan jumlah siswa 29 orang dan di SMPIT ALHUSNA Parungkuda Sukabumi dengan jumlah siswa 32 orang.

\section{HASIL DAN PEMBAHASAN}

\section{A. Langkah Pengembangan Model}

Langkah pengembangan model mengacu pada studi literatur dan observasi lapangan. studi literatur dilaksanakan terhadap model pembelajaran yang dijadikan acuan dalam pengembangan model DMM, yaitu studi kepustakaan terhadap model pembelajaran make a macth dan model pembelajaran active debate. Studi literatur juga dilakukan terhadap kesesuaian antara pengembangan model DMM dengan karakteristik mata pelajaran pendidikan kewarganegaraan. Observasi lapangan dilakukan terhadap guru mata pelajaran PKn, sarana dan prasarana sekolah, latar belakang siswa, dan karakteristik siswa. Kolaborasi antara tinjauan teori dengan observasi lapangan menghasilkan draft model DMM.

\section{Tinjauan Teori}

Berdasarkan kajian teori, maka dapat dijelaskan bahwa model pembelajaran debat aktif merupakan model pembelajaran kooperatif dalam bentuk diskusi oleh dua tim/kelompok, yaitu kelompok pro dan kelompok kontra yang berbeda pandangan tentang topik yang ditugaskan. Model pembelajaran debat aktif bisa menjadi teknik yang sangat berguna untuk meningkatkan pemikiran dan refleksi, terutama jika siswa diharapkan mengambil posisi yang bertentangan dengan kemauan mereka. 
Pembelajaran model debat aktif sangat baik digunakan apabila bertujuan untuk melatih siswa untuk berpikir kritis, melatih siswa untuk menyampaikan pendapat secara baik dan benar, mencari kebenaran tentang topik yang sedang hangat atau sedang heboh-hebohnya di bicarakan di masyarakat, melatih siswa untuk memahami alur pikir orang lain yang bersebrangan dengannya, serta melatih siswa untuk menumbuhkan ide atau gagasan baru dari hasil kajian siswa.

Model pembelajaran make a match merupakan model pembelajaran yang teknik mengajarnya dengan mencari pasangan melalui kartu pertanyaan dan kartu jawaban yang harus ditemukan dan didiskusikan oleh pasangan siswa tersebut. Model pembelajaran make a match ini efektif membantu siswa dalam memahami materi melalui permainan mencari kartu pertanyaan dan jawaban, sehingga dapat menciptakan proses pembelajaran yang menyenangkan. Model pembelajaran make a match merupakan model pembelajaran yang menciptakan hubungan baik antara guru dan siswa. guru mengajak siswa bersenang-senang dalam permainan, dan kesenangan tersebut dapat membuat pemahaman siswa terhadap materi pelajaran.

2. Hasil Observasi Lapangan

Berdasarkan observasi lapangan yang dilakukan di beberapa Sekolah Menegah Pertama (SMP) Negeri maupun Swasta di komisariat Cicurug dan informasi dari guru yang mengajar mata pelajaran pendidikan kewarganegaraan diperoleh data bahwa rata-rata nilai ulangan harian PKn selama tiga tahun terakhir masih banyak yang dibawah $\mathrm{kkm}$. Proses kegiatan belajar mengajar $/ \mathrm{kbm}$ mata pelajaran pendidikan kewarganegaraan siswa cenderung tidak tertarik dan tidak aktif. $\begin{array}{crr}\text { Mata pelajaran } & \text { pendidikan } \\ \text { kewarganegaraan dianggap } & \text { sebagai }\end{array}$ pelajaran yang hanya mementingkan hafalan semata, kurang menekankan aspek penalaran sehingga menyebabkan rendahnya minat belajar PKn siswa di sekolah. Keaktifan siswa rendah justru disebabkan oleh pembelajaran yang berpusat pada guru. Guru hanya menggunakan model pembelajaran yang bersifat konvensional dan banyak didominasi guru, sehingga mengakibatkan keaktifan siswa rendah, pembelajaran menjadi terasa kering, tidak menyenangkan, dan membosankan bagi siswa. Dalam hal ini guru sebagai fasilitator pada proses pembelajaran perlu memberikan respon positif secara konkrit dan objektif yang berupaya membangkitkan partisipasi aktif siswa dalam pembelajaran PKn.

Berdasarkan permasalahan di atas, dan dengan adanya kelemahan pada model debate active dan model make a match, maka perlu adanya pengembangan model pembelajaran yang lebih efektif, inovatif, kreatif, dan menyenangkan untuk mencari jalan keluar agar proses pembelajaran terhadap mata pelajaran pendidikan kewarganegaraan tidak semakin membosankan dan untuk meningkatkan hasil belajar serta motivasi dan partisipasi siswa baik bertanya, menjawab, serta memberikan ide atau argumen pada proses pembelajaran pendidikan kewarganegaraan, yaitu dengan cara pengembangan serta penerapan model pembelajaran debate make a match (DMM).

\section{Draft Model}

Berdasarkan tinjauan teori dan observasi lapangan, maka dihasilkan draft model pengembangan DMM yang memiliki langkah-langkah, yaitu : 
a. Guru menyampaikan kompetensi yang ingin dicapai. Pada langkah ini guru diharapkan dapat menyampaikan kompetensi dasar mata pelajaran yang disampaikan sehingga siswa dapat mengukur sejauh mana materi yang harus dikuasai. Di samping itu, guru juga harus menyampaikan indikator-indikator ketercapaian kompetensi dasar sehingga sampai dimana indikatornya dapat dicapai oleh siswa

b. Menyajikan materi sebagai pengantar. Penyajian materi sebagai pengantar adalah sesuatu yang penting. Dari sini guru memberikan momentum permulaan pembelajaran. Kesuksesan dalam proses pembelajaran dapat dimulai dari sini. Hal ini karena guru dapat memberikan motivasi yang menarik perhatian siswa yang belum siap. Dengan motivasi dan teknik yang baik dalam pemberian materi akan menarik minat siswa untuk belajar lebih jauh tentang materi yang dipelajari

c. Mengelompokkan siswa. Siswa dikelompokkan menjadi 3 kelompok (pro, kontra, dan pengamat). Pengelompokkan siswa didasarkan pada kemampuan setiap siswa. Hal ini bertujuan agar kemampuan setiap kelompok yang terbentuk hampir sama

d. Siswa terlebih dahulu mendiskusikan materi/topik yang akan diperdebatkan. Adapun materi/topik sudah diinformasikan oleh guru pada pertemuan sebelumnya

e. Tempatkan kursi dengan posisi berhadapan (tergantung jumlah keseluruhan siswa di kelas) antara kelompok yang pro dan kontra, dan posisikan kelompok pengamat di belakang tim debat secara seimbang.
Susunannya akan tampak seperti gambar dibawah ini :

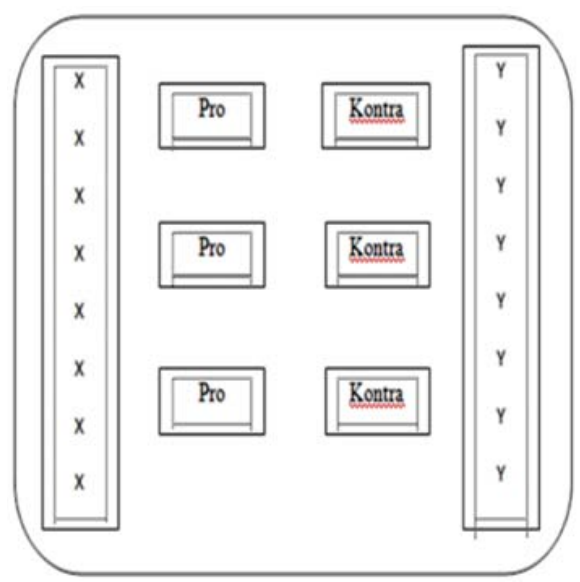

Gambar 1. Posisi Tempat Duduk DMM Keterangan gambar :

Pro : kelompok yang setuju terhadap topik yang diperdebatkan

Kontra: kelompok yang tidak setuju terhadap topik yang diperdebatkan

$X$ : kelompok pengamat

$Y$ : kelompok pengamat

f. Setelah kelompok terbentuk, siswa diminta untuk mendiskusikan serta memperdebatkan antara kelompok yang pro dan kontra tentang topik yang sudah di informasikan pada pertemuan sebelumnya, proses debat ini berlangsung sampai seluruh siswa dari kelompok yang pro dan kontra sudah mengemukakan pendapatnya

g. Ketika debat berlangsung, pastikan untuk memberikan kesempatan yang sama antara kedua kelompok, dan anjurkan siswa lain untuk memberikan catatan yang memuat argument tandingan atau bantahan terhadap pendapat pihak lain. Juga dianjurkan kepada para siswa untuk memberi tepuk tangan atas argument yang disampaikan oleh tim debat 
h. Beri kesempatan kepada kelompok pengamat untuk bertanya kepada kelompok yang pro maupun yang kontra

i. Ketika dirasakan sudah cukup, akhiri perdebatan tersebut, tanpa menyebutkan pemenangnya, kemudian siswa diminta untuk kembali berkumpul.

j. Lakukan diskusi dalam satu kelas penuh tentang apa yang didapatkan oleh siswa dari persoalan yang diperdebatkan, serta siswa harus mengenali apa yang menurut mereka merupakan argument terbaik yang dikemukakan oleh kedua kelompok

k. Siswa yang berasal dari kelompok yang pro dan kontra kemudian bersatu menjadi satu kelompok, misal kelompok A, sedangkan kelompok pengamat menjadi satu kelompok, misal kelompok B

I. Guru memilih dua orang siswa untuk menjadi tim penilai dari kartu yang nanti harus dicocokkan oleh siswa

m. Kelompok A diberi kartu soal, sedangkan kelompok B diberi kartu jawaban, yang sebelumnya sudah disiapkan oleh guru sebanyak jumlah siswa yang hadir di kelas

n. Setiap siswa mendapatkan satu buah kartu

o. Tiap siswa memikirkan soal/jawaban dari kartu yang dipegang

p. Setiap siswa mencari pasangan yang mempunyai kartu yang cocok dengan kartunya (soal/jawaban), dan menyerahkan kepada tim penilai

q. Setiap siswa yang dapat mencocokan kartunya dan dianggap benar oleh tim penilai sebelum batas waktu, maka diberi reward

r. Setelah satu babak, kartu dikocok lagi agar tiap siswa mendapat kartu yang berbeda dari sebelumnya, demikian seterusnya sampai batas waktu yang telah ditentukan oleh guru

s. Guru memfasilitasi siswa dalam membuat rangkuman, mengarahkan, dan memberikan penegasan pada materi pembelajaran yang telah dipelajari

4. Teknik Delphi I

Setelah draft pengembangan model pembelajaran DMM tercipta, maka dilakukan expert judgment dengan teknik Delphi. Expert judgment untuk model dan expert judgment untuk materi.

Teknik Delphi satu dimulai dari penyerahan draft model pembelajaran DMM kepada expert judgment untuk model yaitu bapak Drs. Ade Ahmad Hidayat, M.Pd beliau sebagai pengawas PKn di Kabupaten Sukabumi. Setelah draft model pembelajaran DMM dibaca dan dipelajari oleh beliau, maka untuk Delphi satu tidak ada masukan serta revisi karena expert menganggap draft model pembelajaran DMM sudah cukup bagus dan ideal. Akhirnya draft model pembelajaran DMM di acc oleh expert model dan layak untuk di uji coba terbatas.

Proses teknik Delphi satu dilanjutkan kepada expert judgment untuk content/materi yaitu bapak Dr. Sumardi, M.Pd beliau sebagai dosen Kewiraan di Unpak Bogor, dengan menyerahkan rencana pelaksanaan pembelajaran (RPP) serta instrument penilaian kognitif, afrktif, dan psikomotor. Masukan dan revisi dari expert judgment untuk content/materi adalah sebagai berikut :

a. Dalam tujuan pembelajaran di RPP harus lebih rinci karena disesuaikan dengan tingkatan kognitif, yaitu C1 sampai C4

b. Validasi dan reliabilitas instrumen penilaian kognitif 
Selanjutnya peneliti memperbaiki dan melaksanakan masukan dari expert content dengan merevisi RPP dan mengadakan validasi dan reliabilitas terhadap instrument penilain kognitif. Setelah mengadakan perbaikan akhirnya RPP dan instumen penilaian kognitif di acc oleh expert conten dan layak di uji coba terbatas.

Jadi hasil dari teknik Delphi satu, yaitu tidak ada perubahan pada draft model pengembangan DMM, dan yang ada perubahan hanya pada materi mata pelajaran PKn saja sebagaimana dijelaskan di atas.

\section{B. Hasil Uji Coba dengan Revisi Model}

\section{Uji Coba Terbatas di SMP Negeri 2 Cicurug Sukabumi}

Pengembangan model pembelajaran debate DMM pada uji coba terbatas tindakan pertama di SMPN 2 Cicurug belum sepenuhnya berjalan dengan baik. Pada uji coba terbatas tindakan pertama, guru model belum sepenuhnya memahami langkahlangkah model DMM, dan belum dapat mengkondisikan siswa selama kegiatan belajar mengajar berlangsung, sehingga masih banyak siswa yang belum aktif dalam mengikuti pembelajaran. Hanya beberapa siswa yang berani mengemukakan pendapat beserta alasan-alasannya dan itupun masih di baca. Hal ini disebabkan karena guru model kurang memotivasi dan membimbing siswa selama proses pembelajaran berlangsung. Pengelolaan waktu yang kurang optimal oleh guru menyebabkan waktu yang diperlukan siswa selama proses pembelajaran tidak sesuai dengan waktu yang tersedia.

Ketika sesi siswa mencari pasangan kartu soal/jawaban suasana kelas ricuh dan agak gaduh, disebabkan tim penilai dari siswa tidak bekerja secara maksimal, dan disebabkan juga karena posisi bangku yang memanjang kebelakang sehingga menyulitkan gerak para siswa untuk lebih aktif mencari pasangan kartu soal/jawaban.

Temuan lain yang terjadi ketika uji coba terbatas di SMP Negeri 2 Cicurug Sukabumi, yaitu guru hanya berdiri didepan saja tidak mengelilingi seluruh kelas atau blocking class yang tidak maksimal.

Pada uji coba terbatas tindakan kedua, guru model telah mampu mengelola pembelajaran dan mengelola waktu dengan cukup baik. Siswa semakin antusias dan aktif selama proses pembelajaran berlangsung, siswa aktif mengemukakan pendapatnya ketika sessi debat, dan siswa terlihat sangat bersemangat serta ceria didalam proses pembelajaran dengan menggunakan model DMM. Tetapi antara kelompok pro dan kelompok kontra pendapatnya sama, dikarenakan topik yang dibahasa ketika tindakan kedua adalah tentang prostitusi online.

Ketika sesi mencari pasangan kartu soal/jawaban untuk penguatan materi, terlihat suasana kelas yang agak gaduh sama ketika tindakan pertama, serta tim penilai dari siswa yang lupa ditunjuk oleh guru, sehingga mengakibatkan suasana kelas yang ramai ditambah dengan posisi bangku yang membuat siswa agak susah bergerak. Sesi mencari pasangan hanya satu kali putaran dan tidak tersedianya waktu untuk mengkonfirmasi kebenaranan dari pasangan kartu yang telah siswa temukan, hanya dua pasangan yang dikonformasi kebenaran atau kecocokan kartu.

Temuan lain yang ada pada uji coba terbatas tindakan kedua adalah siswa yang tergabung dalam kelompok pengamat begitu antusias bertanya kepada kelompok pro dan kontra, tetapi berhubung alokasi waktu 
untuk kelompok pengamat hanya 5 menit saja, menyebabkan hanya dua siswa saja dari kelompok pengamat yang diberi kesempatan untuk bertanya.

2. Refleksi Uji Coba Terbatas

Refleksi dilaksanakan oleh peneliti dengan guru model, para observer dan rekan sejawat, dari diskusi terdapat berbagai hal yang sudah baik dan harus dipertahankan, juga terdapat beberapa temuan yang harus diperbaiki.

Adapun hasil pelaksanaan refleksi dari uji coba terbatas adalah sebagai berikut :

a. Setting Kelas. Pelaksanaan setting kelas dengan memposisikan meja dan kursi berdasarkan denah yang sesuai dengan draft model DMM, tetapi karena ruang kelas yang sempit sehingga adanya keterbatasan dalam gerak siswa maupun guru.

b. Pengelompokan siswa. Masih kurangnya penyebaran kemampuan siswa pada tiap kelompok.

c. Alokasi Waktu. Alokasi waktu kurang memadai mengingat antusiasme siswa yang tinggi pada saat proses pembelajaran dengan menggunakan model DMM, terutama pada sessi debat dari pihak pengamat yang kurang tersedia waktu untuk bertanya kepada kelompok pro/kontra.

d. Media Pembelajaran. Media pembelajaran kurang memadai dan ketika penanyangan materi oleh guru dengan menggunakan infocus tidak jelas terlihat dikarenakan ada pantulan cahaya di dalam ruangan kelas.

e. Langkah-langkah Pembelajaran. Guru masih kaku dalam melaksanakan langkah-langkah model pembelajaran debate make a match/DMM.

f. Aktifitas Guru. Aktifitas guru selama mengajar sudah cukup baik sesuai dengan RPP dan cukup memahamai model DMM walaupun masih agak kaku. Dalam tahap debat, guru hanya fokus berdiri di depan kelas tidak mengelilingi kelas (blocking class) dan pada saat mencari pasangan soal/jawaban, guru kurang mengkoordinir siswa, guru kurang disiplin terhadap alokasi waktu yang ada di RPP, dan guru kurang memberikan informasi mengenai model DMM kepada siswa.

g. Aktifitas siswa. Aktifitas siswa sudah cukup baik dengan keaktifan dan partisipasi dalam debat/diskusi, tetapi masih terlihat agak kacau ketika sessi mencari pasangan kartu soal/jawaban.

h. Sistem reward. Pemberian reward kepada siswa sudah cukup baik dengan memberikan pujian dan benda tapi agar lebih memotivasi siswa pemberian reward harus ditambah dengan yang lebih menarik dan bermanfaat.

\section{Teknik Delphi II}

Setelah uji coba terbatas selesai dilaksanakan, maka peneliti melaporkan temuan-temuan yang terjadi di uji coba terbatas kepada expert judgment untuk model. Melihat permasalahan yang terjadi pada uji coba terbatas, maka dipandang perlu oleh expert judgment untuk model diadakan revisi pada pengembangan model pembelajaran debate make a match/DMM. Untuk lebih jelasnya inilah revisi dari model debate make a match/DMM, yaitu :

a. Revisi pada alokasi waktu ketika kegiatan inti yaitu debat yang awalnya 25 menit menjadi 20 menit, karena untuk memberikan penambahan waktu kepada kelompok pengamat untuk bertanya atau memberikan komentar terhadap kelompok pro dan kontra 
b. Revisi pada langkah-langkah model pembelajaran DMM, yaitu pada tahapan siswa mencari pasangan kartu soal/kartu jawaban

c. Tim penilai ketika sessi mencari pasangan soal/jawaban dirubah dari siswa menjadi guru

d. Revisi pada tata letak tempat duduk siswa

e. Penambahan pada sistem reward bagi siswa yang lebih menarik dan bermanfaat, yaitu dengan memberlakukan sistem reward "star smart" sebagai bahan pertimbangan untuk menambah nilai afektif dan psikomotor.

Peneliti memperbaiki dan melaksanakan masukan dari expert untuk model dengan merevisi model pembelajaran DMM. Langkah-langkah model pembelajaran DMM setelah revisi adalah sebagai berikut :

a. Guru menyampaikan kompetensi yang ingin dicapai. Pada langkah ini guru diharapkan dapat menyampaikan kompetensi dasar mata pelajaran yang disampaikan sehingga siswa dapat mengukur sejauh mana materi yang harus dikuasai. Di samping itu, guru juga harus menyampaikan indikatorindikator ketercapaian kompetensi dasar sehingga sampai dimana indikatornya dapat dicapai oleh siswa.

b. Menyajikan materi sebagai pengantar. Penyajian materi sebagai pengantar adalah sesuatu yang penting. Dari sini guru memberikan momentum permulaan pembelajaran. Kesuksesan dalam proses pembelajaran dapat dimulai dari sini. Hal ini karena guru dapat memberikan motivasi yang menarik perhatian siswa yang belum siap. Dengan motivasi dan teknik yang baik dalam pemberian materi akan menarik minat siswa untuk belajar lebih jauh tentang materi yang dipelajari

c. Mengelompokkan siswa. Siswa dikelompokkan menjadi 3 kelompok (pro, kontra, dan pengamat). Pengelompokkan siswa didasarkan pada kemampuan setiap siswa. Hal ini bertujuan agar kemampuan setiap kelompok yang terbentuk hampir sama

d. Siswa terlebih dahulu mendiskusikan materi/topik yang akan diperdebatkan. Adapun materi/topik sudah diinformasikan oleh guru pada pertemuan sebelumnya

e. Tempatkan kursi dengan posisi berhadapan antara kelompok yang pro dan kontra, serta kelompok pengamat. Susunannya akan tampak seperti gambar dibawah ini :

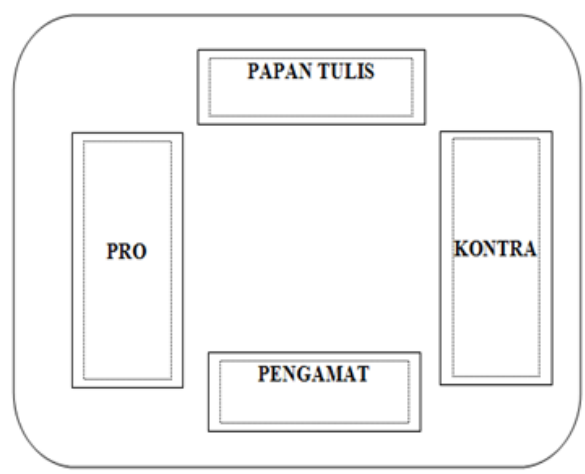

Gambar 2. Posisi Tempat Duduk Pelaksanaan Model DMM setelah revisi

f. Setelah kelompok terbentuk, siswa diminta untuk mendiskusikan serta memperdebatkan antara kelompok yang pro dan kontra tentang topik yang sudah di informasikan pada pertemuan sebelumnya, proses debat ini berlangsung sampai seluruh siswa dari kelompok yang pro dan kontra sudah mengemukakan pendapatnya. 
g. Ketika debat berlangsung, pastikan untuk memberikan kesempatan yang sama antara kedua kelompok, dan anjurkan siswa lain untuk memberikan catatan yang memuat argument tandingan atau bantahan terhadap pendapat pihak lain. Juga dianjurkan kepada para siswa untuk memberi tepuk tangan atas argument yang disampaikan oleh tim debat

h. Beri kesempatan kepada kelompok pengamat untuk bertanya kepada kelompok yang pro maupun yang kontra

i. Ketika dirasakan sudah cukup, akhiri perdebatan tersebut, tanpa menyebutkan pemenangnya

j. Lakukan diskusi dalam satu kelas penuh tentang apa yang didapatkan oleh siswa dari persoalan yang diperdebatkan, serta siswa harus mengenali apa yang menurut mereka merupakan argument terbaik yang dikemukakan oleh kedua kelompok

k. Siswa yang berasal dari kelompok yang pro dan kontra menjadi satu kelompok, misal kelompok $A$, sedangkan kelompok pengamat menjadi satu kelompok, misal kelompok B

I. Kelompok A diberi kartu soal, sedangkan kelompok B diberi kartu jawaban, yang sebelumnya sudah disiapkan oleh guru sebanyak jumlah siswa yang hadir di kelas

m. Setiap siswa mendapatkan satu buah kartu soal/jawaban

n. Tiap siswa memikirkan soal/jawaban dari kartu yang dipegang

o. Setiap siswa mencari pasangan yang mempunyai kartu yang cocok dengan kartunya (soal/jawaban), setelah menemukan pasangan kartunya, kemudian siswa duduk di tempat masing-masing p. Setelah semua siswa duduk kembali di tempatnya masing-masing, kemudian guru mengkonfirmasi kebenaran dari kecocokkan kartu dengan memanggil pasangan ke depan kelas dan bersamasama dengan siswa lainnya menilai kebenaran dari kartu soal/jawaban

q. Setiap siswa yang dapat mencocokan kartunya dan dianggap benar oleh guru sebelum batas waktu, maka diberi reward, pemberian reward berupa "star smart"

r. Reward "star smart" adalah: 1 bintang untuk siswa yang aktif dalam debat/diskusi, 2 bintang untuk siswa yang aktif debat/diskusi dan bertanya, 3 bintang untuk siswa yang aktif debat, bertanya dan menjawab pertanyaan baik dari guru maupun dari siswa, 4 bintang untuk siswa yang aktif debat, bertanya dan menjawab pertanyaan serta dapat menemukan pasangan kartu soal/jawaban, 5 bintang untuk siswa yang aktif debat, bertanya dan menjawab pertanyaan serta cepat menemukan pasangan kartu soal/jawaban sebelum berakhirnya batas waktu yang telah ditentukan

s. Pemberian reward "star smart" sebagai bahan pertimbangan untuk menambah nilai afektif dan psikomotor

t. Guru memfasilitasi siswa dalam membuat rangkuman, mengarahkan, dan memberikan penegasan pada materi pembelajaran yang telah dipelajari

Setelah direvisi maka akhirnya pengembangan model pembelajaran DMM di acc oleh expert model dan layak untuk di uji coba lebih luas. Proses teknik Delphi dua dilanjutkan kepada expert judgment untuk materi yaitu bapak Dr. Sumardi, M.Pd dengan melaporkan temuan-temuan yang 
ada ketika pelaksanaan uji coba terbatas. Adapun temuannya adalah sebagai berikut :

a. Penilaian hasil belajar kognitif siswa berhasil, karena sebanyak $81 \%$ siswa mencapai nilai KKM 75, dan penilaian hasil belajar psikomotor siswa berhasil, karena sebanyak $88 \%$ mencapai nilai KKM 75.

b. Terdapat permasalahan di hasil penilaian afektif. Keberhasilan penilaian afektif siswa kelas VIII B di SMPN 2 Cicurug, hanya mencapai $57 \%$, sedangkan seharusnya adalah mencapai $75 \%$.

Dari permasalahan di atas maka expert judgment untuk content meminta diadakan revisi untuk instumen penilaian afektif. Setelah diadakan revisi terhadap instrument penilaian afektif, maka di acc dan siap untuk dilanjutkan kepada uji coba lebih luas.

\section{Uji Coba Luas di SMP PGRI Cicurug Sukabumi}

Pengembangan model pembelajaran DMM pada uji coba lebih luas di SMP PGRI Cicurug pada tindakan pertama, terdapat beberapa temuan, yaitu siswa kurang terbiasa menggunakan model dalam pembelajaran karena kebiasaan guru yang hanya menggunakan metode konvensional. Siswa tidak berani mengemukakan pendapat dan masih terlihat malu-malu dan kurang percaya diri. Dan ketika sesi mencari pasangan kartu soal/jawaban, pelaksanaannya cukup ramai membuat siswa senang seakan-akan mereka bermain dan adanya konfirmasi dari guru tentang kebenaran kartu yang mereka temukan, walaupun banyak dari siswa yang tidak berhasil menemukan pasangan

Proses pembelajaran tindakan kedua adanya peningkatan dari guru, yaitu dengan menanyangkan video tentang wacana pembangunan gedung baru untuk anggota
MPR yang sesuai dengan topik yang akan diperdebatkan oleh siswa. Siswa sudah mulai berani berdebat dan mulai tumbuh rasa percaya diri, sessi debat sangat seru dan hangat, masing-masing anggota dari kelompok pro dan kontra mengemukakan pendapat beserta alasan-alasannya, dan kelompok pengamat pun ikut terlibat dalam debat, walaupun masih ada siswa yang membaca tulisan dari buku mereka. Ketika sessi mencari pasangan kartu soal/jawaban, suasana ramai terkendali, ruang gerak siswa leluasa dikarena posisi/setting bangku dan meja yang presentatif. Guru mengkonfirmasi kebenaran dari kartu soal/jawaban yang siswa temukan, dan siswa hampir seluruhnya berhasil menemukan pasangan dan benar,

Penilaian hasil belajar kognitif siswa berhasil, karena sebanyak $76 \%$ siswa mencapai nilai KKM 75, Penilaian hasil belajar afektif siswa berhasil, karena sebanyak 90 \% siswa mencapai nilai KKM 75, dan penilaian hasil belajar psikomotor siswa juga berhasil, karena sebanyak $79 \%$ mencapai nilai KKM 75.

5. Refleksi Uji Coba Luas di SMP PGRI Cicurug Sukabumi

Refleksi dilakukan oleh peneliti, guru model, para observer, dan dengan rekan sejawat. Refleksi membahas pelaksanaan kegiatan belajar mengajar dengan menggunakan model pembelajaran DMM baik ketika tindakan pertama maupun tindakan kedua, adapun hasil dari refleksi adalah sebagai berikut :

a. Setting Kelas. Pelaksanaan setting kelas dengan memposisikan meja dan kursi berdasarkan denah yang sesuai dengan draft model DMM hasil dari teknik Delphi satu.

b. Pengelompokan siswa. Penyebaran kemampuan siswa pada tiap kelompok sudah cukup baik dan merata. 
c. Alokasi Waktu. Alokasi waktu yang tersedia di dalam RPP sudah ditentukan untuk setiap langkah-langkah dalam DMM.

d. Media Pembelajaran. Media pembelajaran yang dipakai yaitu tayangan slide power point yang dibantu dengan LCD dan Infokus cukup memadai.

e. Langkah-langkah Pembelajaran. Guru belum terbiasa menggunakan model pembelajaran apapun apalagi model DMM.

f. Aktifitas guru. Aktifitas guru selama mengajar sudah cukup baik sesuai dengan RPP, namun guru belum terbiasa menggunakan model pembelajaran pada kegiatan belajar mengajar, sehingga dalam pelaksanaan model DMM masih terlihat kaku, dan dalam tahap debat, guru terlalu memaksa siswa untuk mengeluarkan pendapatnya, guru terlalu mendominasi proses belajar mengajar, dan guru kurang disiplin terhadap alokasi waktu yang ada di RPP.

g. Aktifitas siswa. Aktifitas siswa sudah cukup baik dengan keaktifan dan partisipasi dalam debat/diskusi, walaupun belum maksimal karena siswa terbiasa dengan metode ceramah guru dan belum terbiasa menggunakan model pembelajaran. Aktifitas siswa ketika sessi mencari pasangan kartu soal/jawaban ramai terkendali.

h. Sistem reward. Pemberian reward kepada siswa sudah cukup baik dengan memberikan pujian, pulpen dan star smart, walaupun belum tertata secara rapi.

6. Uji Coba Luas di SMPIT AL-HUSNA Parungkuda Sukabumi

Pengembangan model DMM pada uji coba lebih luas yang dilaksanakan di SMPIT AL-HUSNA sangat memuaskan baik ketika tindakan pertama maupun ketika tindakan kedua. Guru model memahami langkahlangkah model DMM, sehingga tercipta proses pembelajaran yang aktif, kreatif, efektif dan menyenangkan. Terlihat dari aktivitas siswa ketika sessi debat, sangat berani dalam mengemukakan pendapatnya atas suatu topik yang sudah ditentukan oleh guru dengan berlandaskan alasan-alasan yang kuat.

Ketika siswa berdebat mereka tidak lagi membaca tulisan tapi langsung mengemukakan pendapatnya, kemampuan siswa serta keberanian berbicara merata, sangat baik dan bagus sehingga terjadinya perdebatan yang sengit dan seru antara kelompok pro, kontra dan kelompok pengamat. Guru model hanya mengarahkan sedikit saja, dan para siswa dengan berani dan percaya diri berdebat. Dan ketika sessi mencari pasangan kartu soal/jawaban, suasana kondusif dengan penilaian dari guru, siswa berhasil mencari pasangan dan benar.

Guru tidak lupa memberikan reward kepada siswa yang pertama kali menemukan pasangan kartu soal/jawaban dan benar, baik reward berupa benda maupun reward dengan sistem star smart. Pemberian reward juga diberikan kepada kelompok yang paling aktif dalam proses belajar mengajar di kelas. Siswa terlihat sangat senang dan gembira dalam proses pembelajaran dengan menggunakan model DMM.

Penilaian hasil belajar kognitif siswa berhasil, karena sebanyak 81,25 \% siswa mencapai nilai KKM 77, Penilaian hasil belajar afektif siswa berhasil, karena sebanyak 97 \% siswa mencapai nilai KKM 77, dan penilaian hasil belajar psikomotor siswa berhasil, karena sebanyak $97 \%$ mencapai nilai KKM 77. 
7. Refleksi Uji Coba Luas di SMPIT ALHUSNA Parungkuda Sukabumi

Berdasarkan temuan-temuan pada uji coba lebih luas dari tindakan 1 dan tindakan 2 serta hasil analisis dan pengamatan selama proses pembelajaran yang dilakukan oleh peneliti dan observer maka dilakukan refleksi. Adapun hasil refleksi tim kolaborator dari pelaksanaan uji coba lebih luas di SMPIT AL-HUSNA adalah sebagai berikut :

a. Setting Kelas. Pelaksanaan setting kelas dengan memposisikan meja dan kursi berdasarkan denah yang sesuai dengan draft model DMM hasil dari teknik Delphi satu.

b. Pengelompokan siswa. Penyebaran kemampuan siswa pada tiap kelompok sudah sangat bagus dan merata secara heterogen berdasarkan jenis kelamin, suku dan tingkat prestasi.

c. Alokasi Waktu. Alokasi waktu dalam RPP diterapkan sangat baik oleh guru dalam proses pembelajaran di dalam kelas.

d. Media Pembelajaran. Media pembelajaran sudah sangat presentatif.

e. Langkah-langkah Pembelajaran. Langkahlangkah pembelajaran sesuai dengan model DMM.

f. Aktifitas guru. Aktifitas guru selama mengajar sangat baik sesuai dengan RPP dan sangat memahamai langkah-langkah model pembelajaran debate DMM.

g. Aktifitas siswa. Aktifitas siswa sangat baik terlihat dari keaktifan dan partisipasi dalam debat/diskusi dan dalam sessi mencari pasangan kartu soal/jawaban.

h. Sistem reward. Pemberian reward kepada siswa sudah cukup baik dengan memberikan pujian, benda, dan reward dengan sistem star smart.

\section{Teknik Delphi III}

Setelah pelaksanaan uji coba luas di dua sekolah, kemudian temuan-temuan yang ada didiskusikan dengan expert untuk model, hasil dari diskusi adalah adanya beberapa revisi dan masukan, yaitu :

a. Topik/bahasan yang akan di debatkan oleh siswa harus lebih menarik supaya menggali informasi sebanyak-banyaknya.

b. Perubahan nama pengembangan model pembelajaran dari debate make a match/DMM menjadi debate card match/DCM, dengan alasan supaya ada unsur kebaruan/kekinian dan tidak sama dengan model pembelajaran yang sudah ada.

Dari hasil teknil Delphi ketiga maka tercipta model yang terekomendasi, yaitu sebagai berikut :

Model pembelajaran Debate Card Match (DCM) merupakan model pembelajaran integrative atau kolaborasi dari model make a match dan model active debate. Model DCM menekankan keaktifan siswa dalam setiap proses pembelajaran. Cirinya adalah inovatif dan kreatif. Inovatif artinya setiap pembelajaran harus memberikan sesuatu yang baru, berbeda, dan selalu menarik minat siswa. Sementara kretif artinya setiap pembelajaran harus menimbulkan minat kepada siswa untuk menghasilkan sesuatu atau dapat menyelesaikan suatu masalah dengan menggunakan metoda, teknik, atau cara yang dikuasai oleh siswa yang diperoleh dari proses pembelajaran.

Model DCM sebagai suatu model pembelajaran yang menekankan pada kemampuan siswa untuk pandai berbicara dan mengemukakan pendapat serta mempertahankan pendapatnya, dan di lanjutkan dengan mencari pasangan kartu 
yang merupakan soal/jawaban. Salah satu keunggulan teknik ini adalah siswa dilatih untuk mengemukakan pendapat atau pemikirannya dan mempertahankan pendapatnya yang disertai dengan alasanalasan yang masuk akal dan dapat di terima, serta siswa mencari pasangan soal/jawaban sambil belajar mengenai suatu konsep atau topik dalam suasana yang menyenangkan.

Proses pembelajaran dengan menggunakan model DCM, dimulai dengan pemberian informasi terlebih dahulu pada pertemuan sebelumnya kepada siswa tentang model DCM ini, dengan cara pembagian kelompok yang terdiri dari 3 kelompok, yaitu pro, kontra, dan pengamat, dan pemilihan topik yang akan diperdebatkan oleh siswa yang sesuai dengan materi ajar. Guru dapat mengevaluasi setiap siswa tentang penguasaan materi yang meliputi kedua posisi tersebut dan mengevaluasi seberapa efektif siswa terlibat dalam prosedur debat.

Langkah - langkah model pembelajaran debate card match / DCM:

1) Guru menyampaikan kompetensi yang ingin dicapai. Pada langkah ini guru diharapkan dapat menyampaikan kompetensi dasar mata pelajaran yang disampaikan sehingga siswa dapat mengukur sejauh mana materi yang harus dikuasai. Disamping itu, guru juga harus menyampaikan indikator-indikator ketercapaian kompetensi dasar sehingga sampai dimana indikatornya dapat dicapai oleh siswa

2) Menyajikan materi sebagai pengantar. Penyajian materi sebagai pengantar adalah sesuatu yang penting. Dari sini guru memberikan momentum permulaan pembelajaran. Kesuksesan dalam proses pembelajaran dapat dimulai dari sini. Hal ini karena guru dapat memberikan motivasi yang menarik perhatian siswa yang belum siap. Dengan motivasi dan teknik yang baik dalam pemberian materi akan menarik minat siswa untuk belajar lebih jauh tentang materi yang dipelajari

3) Mengelompokkan siswa. Siswa dikelompokkan menjadi 3 kelompok (pro, kontra, dan pengamat). Pengelompokkan siswa didasarkan pada kemampuan setiap siswa. Hal ini bertujuan agar kemampuan setiap kelompok yang terbentuk hampir sama

4) Siswa terlebih dahulu mendiskusikan materi/topik yang akan diperdebatkan. Adapun materi/topik sudah diinformasikan oleh guru pada pertemuan sebelumnya

5) Topik/bahasan yang akan diperdebatkan harus yang menarik untuk dapat menggali informasi sebanyak-banyaknya dan sesuai dengan materi pelajaran

6) Tempatkan kursi dengan posisi berhadapan antara kelompok yang pro dan kontra, serta kelompok pengamat . Susunannya akan tampak seperti gambar dibawah ini :

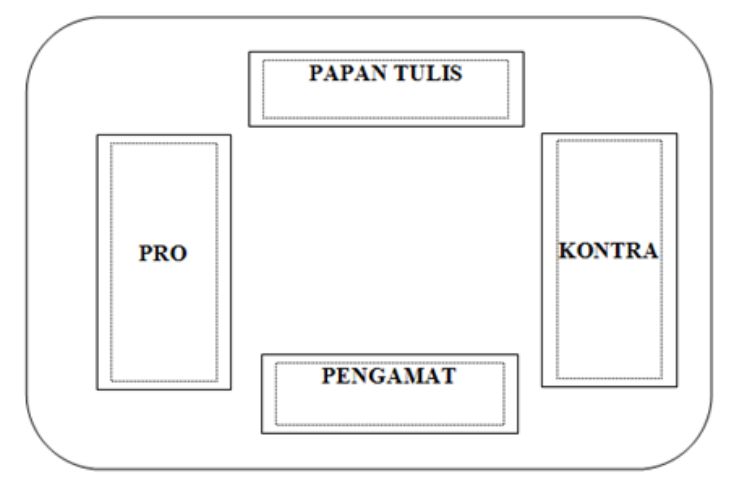

Gambar 3. Posisi Tempat Duduk Pelaksanaan Model DCM

7) Setelah kelompok terbentuk, siswa diminta untuk mendiskusikan serta memperdebatkan antara kelompok yang 
pro dan kontra tentang topik yang sudah di informasikan pada pertemuan sebelumnya, proses debat ini berlangsung sampai seluruh siswa dari kelompok yang pro dan kontra sudah mengemukakan pendapatnya

8) Ketika debat berlangsung, pastikan untuk memberikan kesempatan yang sama antara kedua kelompok, dan anjurkan siswa lain untuk memberikan catatan yang memuat argument tandingan atau bantahan terhadap pendapat pihak lain. Juga dianjurkan kepada para siswa untuk memberi tepuk tangan atas argument yang disampaikan oleh tim debat

9) Beri kesempatan kepada kelompok pengamat untuk bertanya kepada kelompok yang pro maupun yang kontra

10) Ketika dirasakan sudah cukup, akhiri perdebatan tersebut, tanpa menyebutkan pemenangnya

11) Lakukan diskusi dalam satu kelas penuh tentang apa yang didapatkan oleh siswa dari persoalan yang diperdebatkan, serta siswa harus mengenali apa yang menurut mereka merupakan argument terbaik yang dikemukakan oleh kedua kelompok

12) Siswa yang berasal dari kelompok yang pro dan kontra menjadi satu kelompok, misal kelompok $A$, sedangkan kelompok pengamat menjadi satu kelompok, misal kelompok B

13) Kelompok A diberi kartu soal, sedangkan kelompok B diberi kartu jawaban, yang sebelumnya sudah disiapkan oleh guru sebanyak jumlah siswa yang hadir di kelas

14) Setiap siswa mendapatkan satu buah kartu soal/jawaban

15) Tiap siswa memikirkan soal/jawaban dari kartu yang dipegang

16) Setiap siswa mencari pasangan yang mempunyai kartu yang cocok dengan kartunya (soal/jawaban), setelah menemukan pasangan kartunya, kemudian siswa duduk di tempat masingmasing

17) Setelah semua siswa duduk kembali di tempatnya masing-masing, kemudian guru mengkonfirmasi kebenaran dari kecocokkan kartu dengan memanggil pasangan ke depan kelas dan bersamasama dengan siswa lainnya menilai kebenaran dari kartu soal/jawaban

18) Setiap siswa yang dapat mencocokan kartunya dan dianggap benar oleh guru sebelum batas waktu, maka diberi reward, pemberian reward berupa "star smart"

19) Reward "star smart" adalah: 1 bintang untuk siswa yang aktif dalam debat/diskusi, 2 bintang untuk siswa yang aktif debat/diskusi dan bertanya, 3 bintang untuk siswa yang aktif debat, bertanya dan menjawab pertanyaan baik dari guru maupun dari siswa, 4 bintang untuk siswa yang aktif debat, bertanya dan menjawab pertanyaan serta dapat menemukan pasangan kartu soal/jawaban, 5 bintang untuk siswa yang aktif debat, bertanya dan menjawab pertanyaan serta cepat menemukan pasangan kartu soal/jawaban sebelum berakhirnya batas waktu yang telah ditentukan

20) Pemberian reward "star smart" sebagai bahan pertimbangan untuk menambah nilai afektif dan psikomotor

21) Guru memfasilitasi siswa dalam membuat rangkuman, mengarahkan, dan memberikan penegasan pada materi pembelajaran yang telah dipelajari. 


\section{Pengujian Keefektifan Model dan Target}

1. Hasil Belajar Kognitif

Hasil belajar kognitif siswa dilakukan pada setiap akhir tindakan. Dapat disimpulkan bahwa terdapat perubahan yang cukup signifikan antara pra tindakan, uji coba terbatas dan uji coba lebih luas, dengan ketuntasan kriteria minimal (KKM) yaitu 75 di SMP Negeri 2 Cicurug dan di SMP PGRI Cicurug dan KKM 77 di SMPIT AL-HUSNA Parungkuda. bahwa rata-rata hasil belajar kognitif siswa mengalami peningkatan dari sebelum dilakukannya tindakan (pra uji coba) sampai uji coba terbatas dan uji coba lebih luas. hasil ini menunjukkan bahwa proses pembelajaran dengan menggunakan pengembangan model DCM dapat meningkatkan hasil belajar siswa pada pelajaran Pendidikan Kewarganegaraan (PKn) serta menunjukkan keberhasilan dalam penelitian R\&D yang telah dilaksanakan.

\section{Hasil Belajar Afektif}

Hasil Belajar afektif siswa yang dilakukan pada setiap akhir tindakan, baik ketika uji coba terbatas maupun uji coba lebih luas dapat dilihat pada tabel 8, 18, dan 27. Ketika uji coba terbatas di SMPN 2 Cicurug penilaian afektif siswa mencapai tingkat ketuntasan $57 \%$, ketika uji coba lebih luas di SMP PGRI Cicurug penilaian afektif siswa mencapai tingkat ketuntasan $90 \%$ dan uji coba lebih luas di SMPIT AL-HUSNA mencapai $97 \%$. Hasil belajar afektif mengalami peningkatan mulai dari uji coba terbatas dan uji coba lebih luas. Peningkatan hasil belajar afektif pada penelitian ini mengalami peningkatan yang signifikan.

\section{Hasil Belajar Psikomotor}

Pengukuran hasil belajar psikomotor dilakukan pada setiap tindakan, yang berarti ada 6 kali pengukuran selama uji coba terbatas dan uji coba lebih luas. Untuk hasil belajar psikomotor menggunakan skala nilai terbalik, dimana skala nilai lima sangat baik, nilai empat baik, nilai tiga cukup, nilai dua kurang, dan nilai satu sangat kurang.

Hasil belajar psikomotor mengalami peningkatan mulai dari kategori cukup, baik dan sangat baik. Kriteria keberhasilan yang ingin dicapai pada penelitian ini adalah $75 \%$ siswa mencapai kategori baik. Hasil belajar psikomotor pada uji coba terbatas sebanyak 88 \% siswa mencapai nilai KKM 75, uji coba lebih luas di SMP PGRI Cicurug sebanyak 79 \% siswa mencapai nilai KKM 75, dan uji coba lebih luas di SMPI AL-HUSNA sebanyak $97 \%$ siswa mencapai KKM 77.

\section{PENUTUP}

Berdasarkan temuan penelitian, analisis data dan refleksi pada setiap uji coba, bahwa penelitian dan pengembangan R\&D menghasilkan model terekomendasi, yaitu pengembangan model pembelajaran DCM. Desain model pembelajaran DCM terdiri dari input, proses, dan output. Input terdiri dari kurikulum yang diterapkan di sekolah, siswa serta guru mata pelajaran PKn.

Proses terdiri dari langkah-langkah model pembelajaran DCM. Proses pembelajaran dengan menggunakan model DCM, dimulai dengan pemberian informasi terlebih dahulu pada pertemuan sebelumnya kepada siswa tentang model DCM ini, dengan cara pembagian kelompok yang terdiri dari 3 kelompok, yaitu pro, kontra, dan pengamat, dan pemilihan topik yang akan diperdebatkan oleh siswa yang sesuai dengan materi ajar. Guru dapat mengevaluasi setiap siswa tentang penguasaan materi yang meliputi kedua posisi tersebut dan mengevaluasi seberapa efektif siswa terlibat dalam prosedur debat. 
Berdasarkan hasil penelitian diatas maka rekomendasi dari peneli yaitu: 1 . Pengembangan model debate card match/DCM perlu disosialisasikan kepada guru-guru agar termotivasi untuk mengembangkan model pembelajaran; 2 . Perlu dilakukan research and development (R\&D) dibidang pendidikan secara periodik; 3. Peningkatan pemahaman tentang penelitian dan pengembangan R\&D dikalangan guru-guru; 4. Model pembelajaran DCM bisa dipakai atau digunakan untuk mata pelajaran yang karakterisitiknya sama dengan mata pelajaran Pendidikan Kewarganegaraan.

\section{DAFTAR PUSTAKA}

Adisusilo, S. (2012). Pembelajaran Nilai karakter. Jakarta: Raja Grafindo Persada.

Borg, W.R. \& Gall, M.D. (1989). Educational Research: An Introduction, Fifth Edition. New York: Longman

Depdiknas. (2006). Pelajaran Pendidikan Kewarganegaraan. Jakarta: Departemen Pendidikan dan Kebudayaan

Dimyati dan Mudjiono. (2006). Belajar dan Pembelajaran. Jakarta: PT Rineka

Djamarah, S.B. \& Zain, A. (2002). Strategi Belajar mengajar.Jakarta: PT Rineka Cipta.

Emzir. (2007). Metodologi Penelitian Pendidikan Kuantitatif dan Kualitatif. Jakarta: Rajawali Pers

Gordon, T. J. (1994). The Delphi Method. Washington,

DC: America Council for the United Nations University.

Hamalik. O. (2008). Kurikulum dan Pembelajaran. Jakarta: Bumi Aksara.

Hamalik, O. (206). Proses Belajar Mengajar. Jakarta: Bumi Aksara.

Hidayat, U.S. (2011). Model-model Pembelajaran Berbasis Pakem. Bandung : CV. Siliwangi\&Co

Huda, M. (2011). Cooperative Learning Metode, Teknik, Struktur Dan Model Penerapan. Yogyakarta: Pustaka Pelajar
Isjoni. (2007). Cooperatif Learning: Mengembangkan Kemampuan Belajar Berkelompok. Bandung: Alfabeta.

Mel Silbermen. (2013). Pembelajaran Aktif 101 Strategi untuk Mengajar Secara Aktif. Jakarta: PT Indekas.

Mulyasa. (2013). Pengembangan dan Implementasi Kurikulum 2013. Bandung: PT Remaja Rosdakarya

Sagala, S. (2006). Konsep dan makna Pembelajaran. Bandung: CV. Alfabeta

Silbermen, M.L. (2006). Active Learning. Strategi Pembelajaran Siswa Aktif. Bandung: Nusamedia.

Shoimin, A. (2014). Model Pembelajaran Inovatif dalam Kurikulum 2013. Yogyakarta: Ar-Ruzz Media.

Sudjana, N. (2009). Penilaian Hasil Proses Belajar Mengajar. Bandung: PT Remaja Rosdakarya

Sugiyono. (2013). Metode Penelitian Pendidikan Pendekatan Kuantitatif, Kualitatif, dan R\&D. Bandung : Alfabeta

Sugiyono. (2012). Metode Penelitian Administrasi. Bandung: Alfabeta.

Sugiyono. (2012). Metode Penelitian Kuantitatif, Kualitatif, dan R\&D. Bandung: Alfabeta.

Sukmadinata \& Syaodah, N. (2005). Metode Penelitian Pendidikan. Bandung: PT Remaja Rosdakarya

Suprijono, A. (2010). Cooperatif Learning Teori \& Aplikasi PAIKEM. Yogyakarta: Pustaka pelajar

Surya, M. (2004). Psikologi Pembelajaran \& Pengajaran. Bandung: Pustaka Bani Quraisy.

Suyono \& Hariyanto. (2011). Belajar dan Pembelajaran. Bandung: PT Remaja Rosdakarya

Syah, M. (2000). Psikologi Pendidikan dengan Pendekatan Baru. Bandung: PT Remaja Rosdakarya.

Trianto. Mendesain Model Pembelajaran InovatifProgresif. Jakarta: Prenada Media Group, 2010 